\title{
Pengaruh Model Pembelajaran Cooperative Integrated Reading And Composition Berbantuan Peta Konsep Terhadap Kemampuan Membaca Pemahaman
}

\author{
Ni Gusti Ayu Mirah Wirandari ${ }^{1}$, Maria Goreti Rini Kristiantari ${ }^{2}$ \\ ${ }^{12}$ Prodi Pendidikan Guru Sekolah Dasar, FIP \\ Universitas Pendidikan Ganesha \\ Singaraja, Indonesia \\ e-mail: ayu.mirah.wirandari@undiksha.ac.id ${ }^{1}$, mariagoretirini.kristiantari@undiksha.ac.id ${ }^{2}$
}

\begin{abstract}
Abstrak
Penelitian ini bertujuan untuk mengetahui pengaruh model Cooperative Integrated Reading and Composition berbantuan peta konsep terhadap kemampuan membaca pemahaman siswa kelas V SD Gugus I Kecamatan Gianyar Tahun Ajaran 2018/2019. Desain penelitian ini adalah Penelitian Eksperimen semu dengan rancangan posttest only control group design. Populasi penelitian seluruh siswa kelas V SD Gugus I Kecamatan Gianyar yang terdiri dari 34 siswa dari 12 kelas 7 SD. Sampel penelitian siswa kelas V A SDN 5 Gianyar sebanyak 29 siswa sebagai kelompok eksperimen dan siswa kelas V A SDN 7 Gianyar sebanyak 29 siswa sebagai kelompok kontrol. Pengumpulan data dilakukan dengan menggunakan tes objektif pilihan ganda biasa. Hasil penelitian menunjukkan bahwa kemampuan membaca pemahaman siswa yang dibelajarkan menggunakan model Cooperative Integrated Reading and Composition berbantuan peta konsep memiliki nilai rata-rata 85.05 dan kemampuan membaca pemahaman siswa yang dibelajarkan menggunakan pembelajaran konvensional memiliki nilai rata-rata 74.01. Berdasarkan hasil analisis uji-t diperoleh $t_{\text {hit }}=8.7619$ dan $t_{\text {tabel }}=2.000$ sehingga $t_{\text {hit }}=8.7619>t_{\text {tabel }}=2.000$. Hal ini berarti terdapat perbedaan kemampuan membaca pemahaman siswa kelompok eksperimen dan kelompok kontrol. Jadi, model Cooperative Integrated Reading and Composition berbantuan peta konsep berpengaruh terhadap kemampuan membaca pemahaman siswa kelas V SD Gugus I Kecamatan Gianyar.
\end{abstract}

Kata-kata kunci: circ, peta konsep kemampuan membaca pemahaman

\begin{abstract}
This proposed research tried to find out the effect of Cooperative Integrated Reading and Composition teaching model with mind mapping teaching media towards $5^{\text {th }}$ grader students' reading skill in SD Gugus I Kecamatan Gianyar in 2018/2019academic year. This research design of this proposed research was quasi-experimental with Post Test Only Control Group Design. The population was $5^{\text {th }}$ grader students of SD Gugus I Kecamatan Gianyar Sub which consists of 12 classes from 7 Elementary schools. This samples were the $5^{\text {th }}$ grader of A class in SDN 5 Gianyar with a total of 29 students as the experimental group, and the $5^{\text {th }}$ graders of A class in SDN 7 Gianyar with the total of 29 students as the control group. The data collection was done through multiple choices. This research result showed that the students' reading skill who taught with Cooperative Integrated Reading and Composition model with mind mapping media had an average score of 85.05, and the students' reading skill which who taught with conventional teaching method had an average score of 74.01. Based on the $t$-test, the result collected was $t_{\text {hit }}=8.7619$ and $t_{\text {tabel }}=2.000$ so $t_{\text {hit }}=8.7619>t_{\text {tabel }}=2.000$. From that, there was a different between reading skill's experimental group and control group. Being said, it can be concluded that the application of Cooperative Integrated Reading and Composition model with mind mapping media has a significant effect towards the $5^{\text {th }}$ grader' reading skill of SD Gugus I Kecamatan Gianyar.
\end{abstract}

Keywords: circ, mind mapping, and reading skill. 


\section{Pendahuluan}

Saat ini sudah dilakukan berbagai upaya dan usaha untuk meningkatkan kualitas pendidikan khususnya di tingkat sekolah dasar, antara lain berupa menyempurnakan kurikulum pendidikan dengan memberlakukan kurikulum 2013. Pembelajaran kurikulum 2013 memiliki tujuan yang berpusat pada siswa sehingga mendorong siswa dalam proses pembelajaran untuk aktif dalam mencari informasi dari berbagai sumber dalam situasi nyata.

Pembelajaran di tingkat sekolah dasar pada kurikulum 2013 disajikan menggunakan pendekatan tematik integratif. Mata pelajaran yang kemudian disebut muatan pelajaran, semuanya dipadukan dalam satu buku yang dinamakan buku tematik. Salah satu muatan dalam kurikulum 2013 adalah bahasa Indonesia. Bahasa Indonesia adalah pembelajaran yang diarahkan untuk meningkatkan kemampuan siswa dalam berkomunikasi dengan bahasa Indonesia baik secara lisan maupun tulisan (Susanto, 2013).

Dalam pembelajaran bahasa Indonesia siswa diarahkan agar menguasai kaidah-kaidah kebahasaan yang merupakan dasar bagi siswa untuk memasuki dunia ilmu pengetahuan secara lebih mendalam. Pembelajaran bahasa Indonesia tidak terlepas dari empat aspek keterampilan dasar berbahasa. Keterampilan berbahasa merupakan keterampilan yang sangat penting untuk dikuasai, mengingat kemampuan seseorang dalam berbahasa kerap dijadikan tolok ukur kecerdasan seseorang. Oleh karena itu, siswa diarahkan untuk meningkatkan kemampuan dalam berkomunikasi menggunakan bahasa Indonesia yang baik dan benar. Keempat aspek tersebut yang ada dalam keterampilan berbahasa yaitu keterampilan menyimak, keterampilan berbicara, keterampilan membaca, dan keterampilan menulis. Setiap keterampilan memiliki hubungan yang erat dengan keterampilan yang lain.

Dari keempat keterampilan berbahasa, keterampilan membaca merupakan modal utama setiap orang dalam memperoleh informasi maupun wawasan secara tertulis. Selain itu, aktivitas membaca dalam dunia pendidikan merupakan hal yang sangat penting, karena sebagian besar ilmu dan berbagai informasi diperoleh melalui kegiatan membaca, sehingga keterampilan membaca yang dimiliki oleh seseorang mempengaruhi wawasan pengetahuan yang dimilikinya. Keterampilan membaca pada dasarnya hanya dapat diperoleh dan dikuasai dengan jalan praktik dan latihan yang banyak. Praktik dan latihan ini dalam jenjang pendidikan formal harus dilaksanakan dalam keadaan nyaman, menarik, dan menyenangkan untuk menumbuhkan dan mengembangkan yang dimiliki siswa.

Dalman (2017:5) menyatakan, 'reading is the heart of education' yang artinya membaca merupakan jantung pendidikan. Dalam hal ini, siswa yang sering membaca, pendidikannya akan maju dan ia akan memiliki wawasan yang luas. Tentu saja hasil membacanya itu akan menjadi pengetahuan dan pengalaman yang dimiliki. Jadi, semakin sering membaca, maka semakin besarlah peluang dan pengalaman yang akan dimiliki. Hal inilah yang melatarbelakangi banyak orang yang mengatakan bahwa membaca sama dengan membuka jendela dunia. Dengan membaca kita dapat mengetahui seisi dunia dan pola pikirpun akan berkembang.

Dengan mengetahui betapa pentingnya kegiatan membaca, maka di tingkat sekolah dasar telah dilakukan suatu gerakan yang berupaya menumbuhkan budi pekerti siswa yang bertujuan agar siswa memiliki budaya membaca sehingga tercipta pembelajaran sepanjang hayat yang dinamakan Gerakan Literasi Sekolah (GLS). Kegiatan rutin ini dilaksanakan untuk menumbuhkan minat baca siswa serta meningkatkan kemampuan membaca, kegiatan ini melibatkan seluruh warga sekolah untuk mewujudkan pembiasaan membaca yang dilakukan dengan kegiatan 15 menit membaca.

Berdasarkan hasil informasi yang diperoleh dari seluruh wali kelas V di Gugus I Kecamatan Gianyar, disampaikan bahwa kegiatan pembelajaran yang berlangsung belum optimal, khususnya pada salah satu komponen keterampilan berbahasa yaitu kemampuan membaca pemahaman. Sebagian besar siswa merasa bahwa membaca merupakan kegiatan yang membosankan. Siswa beralasan bahwa dengan membaca akan sulit untuk mendapatkan informasi yang diinginkan, terbatasnya waktu, gangguan-gangguan dari teman lain dan adanya banyak aturan dalam kegiatan membaca menjadikan membaca menjadi kegiatan yang sulit dan membosankan. Hal ini tidak terlepas dari belum dibiasakannya siswa untuk membaca dengan benar dan menyenangkan dalam kesehariannya, sehingga menyulitkan siswa dalam kegiatan membaca

Untuk mencapai keberhasilan dalam mengembangkan keterampilan berbahasa, maka diperlukan sebuah strategi pembelajaran yang tepat sesuai dengan tujuan dan karakteristik 
siswa yang dibelajarkan. Guru dalam hal ini berperan aktif dalam menentukan berbagai macam model pembelajaran yang mampu melibatkan siswa secara aktif mengembangkan kemampuan tersebut. Penggunaan model pembelajaran yang variatif, yang melibatkan keempat komponen keterampilan berbahasa tentunya akan memberikan pengaruh pada penguasaan kemampuan berbahasa siswa.

Permasalahan sederhana yang belum banyak mendapat perhatian tersebut dapat diatasi dengan menerapkan model Cooperative Integrated Reading and Composition berbantuan peta konsep. Menurut Shoimin (2014:51) "Model Cooperative Integrated Reading and Composition merupakan model pembelajaran khusus mata pelajaran bahasa dalam rangka membaca dan menemukan ide pokok, pokok pikiran, atau tema sebuah wacana". Penerapan model pembelajaran ini mendorong siswa mengembangkan kemampuan-kemampuan yang dimiliki sebagai pembaca dan pembelajar aktif. Sehingga berpotensi menumbuhkan minat dan semangat belajar siswa yang akan berpengaruh terhadap kemampuan membaca pemahaman siswa. Dalam menggunakan model pembelajaran ini, setiap siswa akan bertanggung jawab terhadap tugas kelompok. Setiap anggota kelompok saling mengeluarkan ide-ide untuk memahami suatu konsep dan menyelesaikan tugas, sehingga terbentuk pemahaman dan pengalaman belajar yang lama.

Selain harus menggunnakan model pembelajaran yang tepat di dalam kelas, penggunaan media juga memiliki peranan penting dalam proses pembelajaran. Arsyad (2017:10) berpendapat, "media pembelajaran adalah segala sesuatu yang dapat digunakan untuk menyampaikan pesan atau informasi dalam proses belajar mengajar sehingga dapat merangsang perhatian dan minat siswa dalam belajar". Salah satu media yang dapat membantu mengoptimalkan penggunaan model pembelajaran Cooperative Integrated Reading and Composition adalah media peta konsep. Dengan menggunakan media ini siswa mampu menuliskan ide-ide pokok dan makna yang terdapat dalam sebuah wacana yang dibaca, hasil dari pemahaman yang didapat dari membaca dapat ditulis pada bagan-bagan yang dapat menghubungkan antara konsep-konsep materi yang sedang dipelajari. sehingga dengan demikian siswa akan lebih mudah untuk memahami isi wacana yang telah dibaca (Wibowo, 2016).

Berdasarkan pemaparan tersebut, maka peneliti tertarik untuk melakukan penelitian dengan judul Pengaruh Model Cooperative Integrated Reading and Composition Berbantuan Peta Konsep terhadap Kemampuan Membaca Pemahaman Siswa Kelas V SD Gugus I Kecamatan Gianyar Tahun Ajaran 2018/2019.

Membaca secara sederhana dikatakan sebagai proses membunyikan lambang bahasa tertulis. Rahim (2018:2) berpendapat, "membaca adalah proses menerjemahkan simbol tulis (huruf) ke dalam kata-kata lisan". Sejalan dengan pendapat tersebut Artati (2009:2) mengemukakan, "dari segi linguistik, membaca adalah suatu proses penyandian kembali dan pembacaan sandi (decoding). Sebuah aspek pembacaan sandi adalah menghubungkan katakata tulis dengan makna bahasa lisan yang mencakup pengubahan tulisan/cetakan menjadi bunyi yang bermakna". Dalman (2017:5) mengemukakan, membaca merupakan kegiatan atau proses kognitif yang berupaya untuk menemukan berbagai informasi yang terdapat dalam tulisan. Hal ini berarti membaca merupakan proses berpikir untuk memahami isi teks yang dibaca. Oleh sebab itu, membaca bukan hanya sekedar melihat kumpulan huruf yang telah membentuk kata, kelompok kata, kalimat, paragraf dan wacana saja, tetapi lebih dari itu bahwa membaca merupakan kegiatan memahami dan menginterpretasikan lambang/tanda/tulisan yang bermakna sehingga pesan yang disampaikan penulis dapat diterima oleh pembaca. Berdasarkan pendapat para ahli mengenai definisi membaca, dapat dirangkum bahwa membaca adalah kegiatan atau proses yang dilakukan oleh pembaca dalam meresapi untuk memperoleh informasi atau pesan dengan menghubungkan tulisan-tulisan yang terdapat dalam bacaan.

Membaca mempunyai tujuan, karena seseorang yang membaca dengan suatu tujuan, cenderung lebih memahami dibandingkan dengan orang yang tidak mempunyai tujuan. Membaca bertujuan untuk mencari informasi dan memahami makna bacaan. Makna atau arti erat sekali berhubungan dengan maksud tujuan membaca. Dalam kegiatan membaca di kelas, guru seharusnya menyusun tujuan membaca dengan menyediakan tujuan khusus yang sesuai atau dengan membantu mereka menyusun tujuan membaca siswa itu sendiri. Menurut Rahim (2018:11-12) tujuan membaca mencakup: a) kesenangan, b) menyempurnakan membaca nyaring, c) menggunakan strategi tertentu, d) memperbaharui pengetahuannya tentang suatu topik, e) mengaitkan informasi baru dengan informasi yang telah diketahuinya, f) memperoleh informasi untuk laporan lisan atau tertulis, g) mengkonfirmasikan atau menolak prediksi, h) 
menampilkan suatu eksperimen atau mengaplikasikan informasi yang diperoleh dari suatu teks dalam beberapa cara lain dan mempelajari tentang struktur teks, i) menjawab pertanyaanpertanyaan yang spesifik. Berdasarkan pendapat para ahli tersebut, dapat dirangkum bahwa tujuan membaca adalah memperoleh informasi dari suatu bacaan. Membaca juga bertujuan menyerap informasi, pengetahuan, wawasan dan mengetahui maksud dan tujuan pengarang dalam suatu bacaan secara tertulis yang dilafalkan secara lisan.

Membaca pemahaman merupakan proses kegiatan yang bertujuan untuk memahami suatu teks. "Membaca pemahaman adalah jenis membaca untuk memahami : a) standarstandar atau norma-norma kesastraan, b) resendi kritis, c) drama tulis, d) pola fiksi (Arini, 2006:74). bacaan sehingga memperoleh informasi yang terkandung dalam teks tersebut.

Model pembelajaran Cooperative Integrated Reading and Composition merupakan model pembelajaran yang menekankan pembelajaran khusus mata pelajaran bahasa antara kemampuan membaca dan menulis yang bertujuan untuk meningkatkan kemampuan siswa dalam memahami isi bacaan. Model pembelajaran Cooperative Integrated Reading and Composition adalah salah satu model pembelajaran yang menekankan kerjasama siswa dalam satu kelompok belajar. Menurut Ngalimun (2017:343) "terjemahan model Cooperative Integrated Reading and Composition adalah komposisi terpadu membaca dan menulis secara kooperatif kelompok". Model Cooperative Integrated Reading and Composition merupakan model pembelajaran khusus mata pelajaran bahasa dalam rangka membaca dan menemukan ide pokok, pokok pikiran atau tema sebuah bacaan. Kelompok belajar ditentukan berdasarkan kemampuan yang dimiliki siswa secara beragam.

Pembelajaran kooperatif tipe Cooperative Integrated Reading and Composition dari segi bahasa dapat diartikan sebagai suatu model pembelajaran kooperatif yang mengintegrasikan suatu bacaan secara menyeluruh kemudian mengomposisikannya menjadi bagian-bagian yang penting (Shoimin, 2014). Salvin (2015:200-201) berpendapat, Model Cooperative Integrated Reading and Composition adalah sebuah program yang komprehensif untuk mengajari pelajaran membaca, menulis, dan seni berbahasa pada kelas yang lebih tinggi di sekolah dasar. Satu fokus dari kegiatan-kegiatan Cooperative integrated Reading and Composition sebagai cerita dasar adalah membuat penggunaan waktu tindak lanjut menjadi lebih efektif. Para siswa yang bekerja di dalam tim-tim kooperatif dari kegiatan-kegiatan ini, yang dikoordinasikan dengan pengajaran kelompok membaca, supaya dapat memenuhi tujuantujuan dalam bidang-bidang lain seperti pemahaman membaca, kosa kata, pembacaan pesan, dan ejaan. Para siswa termotivasi untuk saling bekerja satu sama lain dalam kegiatan-kegiatan ini atau rekognisi lainnya yang didasarkan pada pembelajaran seluruh anggota tim. Tujuan model pembelajaran Cooperative Integrated Reading and Composition menurut Abidin (2016:92) adalah pada dasarnya untuk meningkatkan kemampuan siswa dalam memahami isi bacaan sekaligus membina kemampuan menulis reproduksi atas bahan bacaan yang dibacanya. Model Cooperative Integrated Reading and Composition dapat membantu guru memadukan kegiatan membaca dan menulis sebagai kegiatan integratif dalam pelaksanaan pembelajaran membaca.

Media belajar adalah segala sesuatu yang dapat digunakan untuk menyalurkan pesan (bahan pembelajaran) yang ingin disampaikan penulis sehingga dapat merangsang perhatian, minat, pikiran dan perasaan siswa dalam kegiatan pembelajaran untuk mencapai tujuan pembelajaran tertentu Kosasih (2014). Media pembelajaran merupakan alat untuk membantu siswa dalam memahami suatu materi yang sedang dipelajari.

Peta konsep adalah suatu teknik asesmen yang dapat digunakan dalam proses pembelajaran maupun untuk menentukan tingkat pencapaian peserta didik dalam belajar (Yusuf, 2015:289). Peta konsep merupakan inovasi baru yang penting untuk membantu anak untuk menghasilkan pembelajaran bermakna dalam kelas. Dalam peta konsep siswa dilatih untuk mengidentifikasi ide-ide pokok yang berhubungan dengan suatu topic dan menyajikannya ke dalam suatu pola. Adapun langkah-langkah dalam membuat peta konsep adalah 1) membaca bacaan, 2) memperhatikan apa yang penting dalam bacaan, 3) menuliskan secaa singkat apa yang dianggap penting, 4) menjelaskan yang mana yang disebut konsep dan yang mana disebut kata peghubung yang biasanya berupa kata kerja, dan 5) menempatkan konsepkonsep dan kata-kata penghubung dalam peta konsep.

Media Peta konsep adalah suatu media yang dapat digunakan dalam kegiatan pembelajaran guna mencapai tujuan pembelajaran dengan menggunakan bagan-bagan yang dapat menghubungkan antara konsep-konsep materi yang sedang dipelajari. Model pembelajaran Cooperative Integrated Reading and Composition merupakan suatu model pembelajaran yang bertujuan meningkatkan kemampuan membaca siswa untuk memahami 
dan mendapatkan informasi dari isi bacaan tersebut. Untuk mmengoptimalkan penggunaan model pembelajaran ini maka dapat dibantu dengan menggunakan media peta konsep karena dengan memadukan model pembelajaran Cooperative Integrated Reading and Composition dengan media peta konsep akan memudahkan siswa dalam memahami konsep-konsep wacana yang ditulis dalam bagan-bagan serta meningkatkan kemampuan membaca pemahaman siswa.

Tahapan atau sintak model pembelajaran Cooperative Integrated Reading and Composition yang dapat diterapkan sebagai berikut. (1) Pada fase ini guru melakukan apersepsi dan menggali pengetahuan awal siswa tentang materi yang akan diberikan. (2) Guru membagi siswa ke dalam beberapa kelompok, dengan memerhatikan keheterogenan akademik. (3) Dengan cara mengenalkan tentang suatu konsep baru yang mengacu pada hasil penemuan selama eksplorasi. (4) Siswa mengomunikasikan hasil temuan-temuannya, membuktikan, memeragakan tentang materi yang dibahas, baik dalam kelompok maupun di depan kelas. (5) Pada fase ini guru memberikan penguatan berhubungan dengan materi yang dipelajari melalui penjelasan-penjelasan ataupun memberikan contoh nyata dalam kehidupan sehari-hari.

Model pembelajaran Cooperative Integrated Reading and Composition juga memiliki beberapa kelebihan. Menurut Shoimin (2014) terdapat beberapa kelebihan dari model Cooperative Integrated Reading and Composition diantaranya sebagai berikut. (1) Cooperative Integrated Reading and Composition sangat tepat untuk meningkatkan kemampuan siswa dalam menyelesaikan soal pemecahan masalah. (2) Dominasi guru dalam pembelajaran berkurang. (3) Siswa termotivasi pada hasil secara teliti karena bekerja dalam kelompok. (4) Para siswa dapat memahami makna soal dan saling mengecek pekerjaannya. (5) Membantu siswa yang lemah. (6) Meningkatkan hasil belajar khususnya dalam menyelesaikan soal yang berbentuk pemecahan masalah. Sejalan dengan pendapat diatas, Huda (2013:221) mengemukakan kelebihan dari model Cooperative Integrated Reading and Composition antara lain. (1) pengalaman dan kegiatan belajar siswa akan selalu relevan dengan tingkat perkembangan anak, (2) kegiatan yang dipilih sesuai dengan dan bertolak dari minat dan kebutuhan siswa, (3) seluruh kegiatan belajar lebih bermakna bagi siswa sehingga hasil belajar siswa akan dapat bertahan lebih lama, (4) pembelajaran terpadu dapat menumbuhkembangkan kemampuan berpikir siswa, (5) pembelajaran terpadu menyajikan kegiatan yang bersifat pragmatis (bermanfaat) sesuai dengan permasalahan yang sering ditemui dalam lingkungan siswa, (6) pembelajaran terpadu dapat menumbuhkan motivasi belajar siswa kearah belajar yang dinamis, optimal, dan tepat guna, (7) pembelajaran terpadu dapat menumbuhkembangkan interaksi sosial siswa, seperti kerja sama, toleransi, komunikasi dan respek terhadap gagasan orang lain, (8) membangkitkan motivasi belajar serta memperluas wawasan dan aspirasi guru dalam mengajar.

Model pembelajaran Cooperative Integrated Reading and Composition merupakan suatu model pembelajaran yang bertujuan meningkatkan kemampuan membaca siswa untuk memahami dan mendapatkan informasi dari isi bacaan tersebut. Untuk mmengoptimalkan penggunaan model pembelajaran ini maka dapat dibantu dengan menggunakan media peta konsep karena dengan memadukan model pembelajaran Cooperative Integrated Reading and Composition dengan media peta konsep akan memudahkan siswa dalam memahami konsepkonsep wacana yang ditulis dalam bagan-bagan serta meningkatkan kemampuan membaca pemahaman siswa.

Adapun tujuan yang ingin dicapai dalam penelitian ini adalah untuk mengetahui pengaruh model pembelajaran Cooperative Integrated Reading and Composition berbantuan peta konsep terhadap kemampuan membaca pemahaman siswa kelas V SD Gugus I Kecamatan Gianyar Tahun Ajaran 2018/2019.

\section{Metode}

Penelitian ini dilaksanakan di SD Gugus I Kecamatan Gianyar. Lokasi ini dipilih karena memiliki aspek pendukung agar penelitian dapat berjalan dengan baik. Adapun aspek pendukung tersebut antara lain seluruh SD di Gugus I Kecamatan Gianyar secara serentak sudah menerapkan kurikulum 2013, lokasi sekolah dalam satu gugus yang cukup berdekatan sehingga lebih memudahkan dalam melaksanakan penelitian, dan juga tidak terdapatnya kelas unggulan di setiap sekolah dalam gugus tersebut. Kelas yang terpilih sebagai kelompok 
eksperimen dan kelompok kontrol secara berturut-turut adalah kelas VA SDN 5 Gianyar dan kelas VA SDN 7 Gianyar.

Adapun waktu penelitian ini dilaksanakan pada bulan November 2018 sampai dengan bulan Juni 2019. Kegiatan yang dilakukan selama penelitian dimulai dari pengajuan judul proposal, revisi judul, penyusunan proposal, bimbingan proposal, seminar proposal, revisi proposal, persiapan penelitian, pengumpulan data, analisis data, penyusunan skripsi dan ujian skripsi. Pelaksanaan penelitian pada masing-masing sampel penelitian dilaksanakan pada bulan April 2019.

Tujuan penelitian ini adalah untuk mengetahui untuk mengetahui pengaruh model pembelajaran Cooperative Integrated Reading and Composition berbantuan peta konsep terhadap kemampuan membaca pemahaman siswa kelas V SD Gugus I Kecamatan Gianyar Tahun Ajaran 2018/2019.Jenis penelitian ini adalah penelitian eksperimen semu dengan rancangan posttest only control group design.

Desain penelitian ini termasuk dalam jenis Quasi Experimental Design yang menggunakan kelompok atau kelas sebagai kelompok atau kelas eksperimen dan kontrol. Sesuai dengan namanya, desain penelitian ini tidak memberikan pre-test baik pada kelompok eksperimen maupun kelompok kontrol. Perlakuan dapat diberikan pada kelompok eksperimen dan kontrol setelah diyatakan setara. Kesetaraan ini dapat dilakukan dengan menggunakan teknik matching. Setelah diberikan perlakuan maka baik kelompok eksperimen maupun kelompok kelompok kontrol diberikan post-test.

Tabel 1.Rancangan Penelitian

\begin{tabular}{ccc}
\hline Kelas & Perlakuan & Post-test \\
\hline Eksperimen & $\mathrm{X}_{1}$ & $\mathrm{O}_{1}$ \\
Kontrol & $\mathrm{X}_{2}$ & $\mathrm{O}_{2}$ \\
\hline
\end{tabular}

Keterangan :

$\mathrm{X}_{1} \quad$ : Perlakuan model pembelajaran Cooperative Integrated Reading and Composition pada kelas eksperimen

$\mathrm{X}_{2} \quad$ : Dibelajarkan secara konvensional pada kelas kontrol

$\mathrm{O} \quad$ : Menyatakan pengamatan akhir (post-test)

Populasi dalam penelitian ini adalah kelas V SD Gugus I Kecamatan Gianyar tahun ajaran 2018/2019 yang terdiri dari 12 kelas dalam 7 sekolah yaitu SDN 1 Gianyar, SDN 2 Gianyar, SDN 3 Gianyar, SDN 4 Gianyar, SDN 5 Giayar, SDN 6 Gianyar, SDN 7 Gianyar. Dalam penelitian ini, sampel yang dipilih yaitu dua kelas sebagai kelas kontrol dan kelas eksperimen. Untuk menentukan kedua sampel dilakukan teknik random sampling atau pengambilan sampel secara acak dengan mengacak kelas bukan siswanya. Dan sampel dalam penelitian ini adalah kelas VA SDN 5 Gianyar sebanyak 29 siswa sebagai kelompok eksperimen dan kelas VA SDN 7 Gianyar sebanyak 29 siswa sebagai kelompok kontrol.

Metode pengumpulan data merupakan cara yang akan digunakan penelitian untuk mengumpulkan data. Pengumpulan data diakukan dengan tes kemampuan membaca pemahaman. Jenis tes yang digunakan untuk mengumpulkan data adalah tes tertulis berbentuk objektif dengan pilihan ganda biasa dengan 4 pilihan jawaban yang mengandung satu jawaban yang paling benar.

Sebelum tes diberikan pada masing-masing kelompok, terlebih dahulu dilakukan validasi secara teoretis dengan menggunakan kisi-kisi dan dikonsultasikan pada ahli, selanjutnya dilakukan validasi empirik dengan jumlah responden 36 siswa. Dari hasil uji instrumen yang meliputi uji validitas, uji daya beda, tingkat kesukaran, dan uji reliabilitas diperoleh 30 butir tes yang dinyatakan valid atau layak digunakan dalam penelitian dari total 40 butir tes yang diuji cobakan.

Metode dan teknik analisis data yang dilakukan adalah menghitung analisis statistik deskriptif dan analisis statistik inferensial. Statistik deskriptif yang dilakukan yaitu menghitung rata-rata (mean), standar deviasi, dan varians. Sedangkan statistik inferensial adalah untuk menguji hipotesis dan menarik kesimpulan berdasarkan hasil pengujian terhadap hipotesis. 
Teknik yang digunakan untuk menganalisis kemampuan membaca pemahaman dalam penelitian ini adalah uji-t. Sebelum uji hipotesis statistik dengan uji t dilakukan, terlebih dahulu dilakukan uji normalitas sebaran data dan uji homogenitas varians dan selanjutnya dilakukan uji parametrik dengan rumus pollad varians.

Dengan demikian, analisis statistik yang digunakan untuk menguji hipotesis dalam penelitian ini adalah uji beda mean (uji t) dengan rumus polled varians, dengan kriteria pada taraf signifikansi $5 \%(\alpha=0,05)$ dan

$\mathrm{dk}=\mathrm{n}_{1}+\mathrm{n}_{2}-2$

Jika harga $\mathrm{t}_{\text {hitung }} \leq \mathrm{t}_{\text {tabel }}$, maka $\mathrm{H}_{0}$ diterima, dan jika harga $\mathrm{t}_{\text {hitung }}>\mathrm{t}_{\text {tabel, }}$, maka $\mathrm{H}_{0}$ ditolak.

\section{Hasil dan Pembahasan}

Penelitian ini merupakan penelitian yang berbentuk quasi experiment atau eksperimen semu dengan menggunakan rancangan posttest only control group design yang dianalisis menggunakan uji-t. Objek dalam penelitian ini adalah kemampuan membaca pemahaman kelas V SD Gugus I Kecamatan Gianyar yang dibelajarkan menggunakan model pembelajaran Cooperative Integrated Reading and Composition Berbantuan Peta Konsep dan kelompok siswa yang dibelajarkan menggunakan pembelajaran konvensional.

Berdasarkan hasil perhitungan analisis data rerata nilai kemampuan membaca pemahaman kelompok eksperimen $(\bar{X}=80.05)$ lebih dari rerata nilai kemampua membaca pemahaman kelompok kontrol $(\bar{X}=74.01)$. Ini berarti bahwa model pembelajaran Cooperative Integrated Reading aand Composition berbantuan Peta Konsep berpengaruh terhadap kemampuan membaca pemahaman siiswa kelas V SD Gugus I Kecamatan Gianyar Tahun Ajaran 2018/2019.

Berdasarkan hasil analisis diperoleh $t_{\text {hitung }}=8.7619$ dan kemudian dibandingkan dengan harga $t_{\text {tabel }}=2.000$ Karena $t_{\text {hitung }}>t_{\text {tabel }}(8.7619>2.000)$, maka hipotesis nol $\left(H_{0}\right)$ ditolak.

Hal ini berarti terdapat pengaruh model pembelajaran Cooperative Integrated Reading and Composition berbantuan Peta Konsep terhadap kemampuan membaca pemahaman siswa kelas V SD Gugus I Kecamatan Gianyar Tahun Ajaran 2018/2019.

Perbedaan kemampuan membaca pemahaman pada kelompok eksperimen dan kelompok kontrol adalah karena meskipun pembelajaran pada kedua kelompok tersebut samasama menggunakan pendekatan saintifik, namun sintaks pembelajaran pada kelompok eksperimen diinovasikan dengan model pembelajaran Cooperative Integrated Reading and Composition berbantuan peta konsep. yang memberikan pengalaman belajar bagi siswa belajar secara ketergantungan positif, bekerja sama dengan tim, berusaha memahami, menyaring, dan menyampaikan suatu materi dengan menentukan ide-ide pokok dalam wacana yang telah dibaca ke dalam bagan-bagan. Sedangkan, pada pembelajaran konvensional di kelas kontrol pembelajarannya hanya sebatas dengan penggunaan pendekatan saintifik tanpa di variasikan dengan berbagai model.

Berdasarkan hal tersebut, maka pembelajaran di kelas eksperimen yang menggunakan model pembelajaran Cooperative Integrated Reading and Composition berbantuan peta konsep telah berhasil meningkatkan minat belajar siswa terhadap kemampuan membaca pemahaman dan membuat siswa belajar dengan baik, serta dapat menguasai materi secara lebih cepat. Diperkuat dengan pendapat Shoimin (2014:51) yang menyatakan, "Model Cooperative Integrated Reading and Composition merupakan model pembelajaran khusus mata pelajaran bahasa dalam rangka membaca dan menemukan ide pokok, pokok pikiran, atau tema sebuah wacana". Penerapan model pembelajaran ini mendorong siswa mengembangkan kemampuankemampuan yang dimiliki sebagai pembaca dan pembelajar aktif. Sehingga berpotensi menumbuhkan minat dan semangat belajar siswa yang akan berpengaruh terhadap kemampuan membaca pemahaman siswa. Dalam menggunakan model pembelajaran ini, setiap siswa akan bertanggung jawab terhadap tugas kelompok. Setiap anggota kelompok saling mengeluarkan ide-ide untuk memahami suatu konsep dan menyelesaikan tugas, sehingga terbentuk pemahaman dan pengalaman belajar yang lama.

Dengan demikian, hasil kemampuan membaca pemahaman siswa dapat terlihat dari kegiatan pembelajaran, hasil analisis uji hipotesis, dan nilai rerata pada masing-masing kelompok. Hasil temuan penelitian ini relevan dengan penelitian yang pernah dilakukan oleh beberapa peneliti sebelumnya, sehingga dapat memperkuat hasil penelitian yang diperoleh. 
Penelitian yang relevan tersebut adalah Hasil temuan pada penelitian ini sejalan dengan penelitian sebelumnya yang relevan dan memperkuat hasil penelitian oleh Prabawati (2013) menyatakan bahwa pengaruh model pembelajaran Cooperative Integrated Reading and Composition berbantuan media gambar berseri dapat menngkatkan kemampuan membaca pemahaman siswa kelas V SD Gugus IV Kecamatan Rendang, Kabupaten Karangasem. Selanjutnya penelitian dari Kariesma (2014) menyatakan bahwa penerapan model pembelajaran Cooperative Integrated Reading and Composition bermedia powerpoint dapat meningkatkan kemampuan membaca bahasa Indonesia siswa di kelas IV SD Gugus I Kuta Badung tahun pelajaran 2013/2014.

Berdasarkan hasil dan pembahasan tersebut, dapat dirangkum bahwa pembelajaran menggunakan model pembelajaran Cooperative Integrated Reading and Composition berbantuan peta kosep berpengaruh terhadap kemampuan membaca pemahaman siswa kelas V SD Gugus I Kecamatan Gianyar Tahun Ajaran 2018/2019.

\section{Simpulan dan Saran}

Berdasarkan hasil analisis uji-t pada kelompok eksperimen dan kelompok kontrol diperoleh $\mathrm{t}_{\text {hitung }}=8.7619$. Nilai tersebut kemudian dibandingkan dengan nilai $\mathrm{t}_{\text {tabel }}$ dengan $\mathrm{dk}=56$ dan taraf signifikansi $5 \%(\alpha=0,05)$ sehingga diperoleh harga $t_{\text {tabel }}=2.000$. Karena $t_{\text {hitung }}=$ 8.7619> $t_{\text {tabel }}$ 2.000, maka Hal ini berarti terdapat perbedaan kemampuan membaca pemahaman siswa kelompok eksperimen dan kelompok kontrol. Dengan demikian, dapat disimpulkan bahwa penerapan model Cooperative Integrated Reading and Composition berbantuan peta konsep berpengaruh terhadap kemampuan membaca pemahaman siswa kelas V SD Gugus I Kecamatan Gianyar Tahun Ajaran 2018/2019.

Adapun saran yang ingin disampaikan melalui penelitian ini yaitu: (1)Kepada Guru dan Sekolah, model Cooperative Integrated Reading and Composition dapat dijadikan sebagai acuan dalam pemilihan model pembelajaran yang sesuai dengan kurikulum, muatan pembelajaran dan karakteristik siswa yang dibelajarkan. Kegiatan pembelajaran akan lebih menarik jika dapat divariasikan dengan penerapan model pembelajaran yang ditetapkan dalam Kurikulum 2013. Salah satu model yang direkomendasikan yaitu penerapan pembelajaran dengan model Cooperative Integrated Reading and Composition. (2) Kepada Peneliti Lain, peneliti lain yang berminat untuk mengadakan penelitian lebih lanjut mengenai model Cooperative Integrated Reading and Composition dengan kaitannya terhadap kemampuan membaca pemahaman siswa maupun bidang ilmu lainnya, agar lebih memperhatikan kendalakendala yang dialami dalam penelitian ini sebagai bahan pertimbangan dalam melakukan perbaikan dan penyempurnaan penelitian yang hendak dilaksanakan.

\section{Daftar Pustaka}

Abidin, Yunus. 2016. Pembelajaran Membaca Berbasis Pendidikan Karakter. Bandung: PT Refika Aditama.

Arini, dkk. 2009. Peningkatan Keterampilan Berbahasa Indonesia Berbasis Kompetensi. Singaraja: Universitas Pendidikan Ganesha.

Arsyad, Azhar. 2017. Media Pembelajaran. Jakarta: Rajawali Pers.

Dalman. 2017. Keterampilan Membaca. Jakarta: PT Raja Grafindo Persada.

Huda, Miftahul. 2013. Model-Model Pengajaran dan Pembelajaran: Isu-isu Metodis dan Paradigmatis. Yogyakarta: Pustaka Belajar.

Huda, Miftahul. 2013. Model-Model Pengajaran dan Pembelajaran: Isu-isu Metodis dan Paradigmatis. Yogyakarta: Pustaka Belajar.

Kariesma, Wahyu. 2014. "Pengaruh Model Pembelajaran CIRC Bermedia Powerpoint Terhadap Keterampilan Membaca Pada Bahasa Indonesia Kelas IV SD Gugus I Kuta Badung". Jurnal Online Universitas Pendidikan Ganesha. Tersedia pada file:///C:/Users/JAMCOM/Documents WISUDA\%20SOON/JURNAL\%205.pdf . (diakses pada tanggal 23 Desember 2018). 
Kosasih. 2014. Strategi Belajar dan Pembelajaran Implementasi Kurikulum 2013. Bandung: Yrama Widya.

Ngalimun. 2017. Strategi Pembelajara Dilengkapi dengan 65 Model Pembelajaran. Yogyakarta: Parama llmu.

Prabawati, Ayu Dwi Candra. 2013. "Pengaruh Model CIRC Berbantuan Media Gambar Berseri Terhadap Kemampuan Membaca Pemahaman Pada Siswa Kelas V Sd Gugus IV Kecamatan Rendang". Jurnal Online Universitas Pendidikan Ganesha. Tersedia pada file://C:/Users/ JAMCOM/Documents/WISUDA\%20SOON/jurnal\%20circ.pdf. (diakses pada tanggal 23 Desember 2018).

Rahim, Farida. 2018. Pengajaran Membaca di Sekolah Dasar. Jakarta: Sinar Grafika Offset.

Shoimin, Aris. 2014. 68 Model Pembelajaran Inovatif dalam Kurikulum 2013. Yogyakarta: ArRuzz Media.

Slavin, Robert E. 2015. Cooperative Learning: Teori, Riset dan Praktik. Bandung: Nusa Media.

Susanto, Ahmad. 2013. Teori Belajar \& Pembelajaran di Sekolah Dasar. Jakarta: Prenadamedia Group.

Wibowo, dkk. 2016. "Penggunaan Strategi Pq4r Berbantuan Peta Konsep Dalam Membaca Pemahaman Teks Cerita Pendek Sesuai Gaya Kognitif Siswa”. Jurnal Online Universitas Negeri Malang. Tersedia pada file:///C:/Users/JAMCOM/Documents/WISUDA\%20SOON /strategi-pq4r-berbantuan-peta.pdf (diakses pada 27 Desember 2018). 